J. clin. Path. (1952), 5, 67.

\title{
CULTURE OF HUMAN BONE MARROW IN VITRO THE REVERSIBILITY BETWEEN NORMOBLASTIC AND MEGALOBLASTIC SERIES OF CELLS
}

\author{
BY \\ L. G. LAJTHA \\ From the Department of Clinical Pathology, Radcliffe Infirmary, Oxford
}

(RECEIVED FOR PUBLICATION JULY 20, 1951)

Earlier publications have dealt with findings in human bone marrow culture (Rusznyák, Löwinger, and Lajtha, 1948 ; Cairns and Lajtha, 1948 ; Lajtha, 1950 ; Callender and Lajtha, 1951a and b). This communication is concerned with the description of the technique, and with the interrelationship between normoblastic and megaloblastic series of cells.

\section{The Marrow Culture Technique}

The classical methods of tissue culture in vitro are not necessarily ideal for investigations on bone marrow. Most of the emigrating cells from pieces of tissue cultured on a solid supporting framework develop the "fibroblast form," and indeed it is a limitation of the classical tissue culture technique that tissues which cannot develop the "fibroblast form" of cells cannot or are very difficult to culture in vitro.

More physiological conditions are ensured by culturing bone marrow in certain parts of the body (for example, in the anterior chamber of the eye or ear), but there are serious objections to these techniques also. First, under such circumstances cells can emigrate and immigrate from the culture "chamber," and changes in the distribution of the cells are just as difficult to evaluate as changes in- marrow obtained at different intervals of time from the bones. Secondly, although direct observation of the cells by means of a phase contrast microscope is possible in these conditions, the value of microscopy (even that of phase contrast microscopy) is very much limited in differentiating between various types of living cells. For the purpose of bone marrow culture it is obviously essential not to disturb the normal differentiation of the cells, and to be able to observe the changes due to differentiation. It was, therefore, necessary to develop a special technique which would fulfil these requirements.

The principle of culture of cell suspensions was adopted. This has been found to allow similar processes of cell differentiation as occur in bone marrow in vivo, and allowed accurate total and differential counts on the cells. The technique is a modification of Osgood's procedure (Osgood and Brownlee, 1937).

Material.- (1) McCartney bottles $(30 \mathrm{ml}$.) sterilized by autoclave with a hole (approximately $5 \mathrm{~mm}$. diameter) punched in the metal caps. Since rubber is toxic to 
the cultures, the rubber washers are dipped in collodion and dried overnight in an incubator before inserting them into the caps. The caps are then screwed on to the bottles and the bottles sterilized.

(2) Five 30-ml. all-głass syringes; ten 10-ml. all-glass syringes; ten 1-ml. all-glass syringes ; 24 needles (No. 18 s.w.g.), $1 \frac{1}{2}$ in. long ; 24 needles (No. 18 s.w.g.), 3 in. long. These are sterilized by dry heat and stored in glass tubes stoppered with cotton wool.

(3) Heparin-Ringer solution (1:20,000 heparin).

(4) Gey solution (Gey and Gey, 1936), made up as follows :

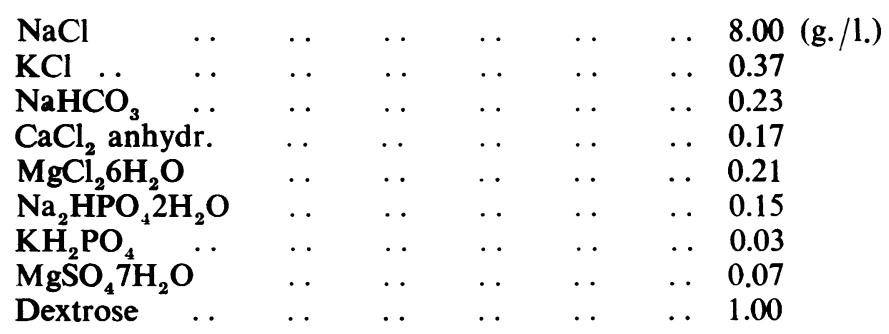

These solutions are Seitz-filtered and kept sterile in McCartney bottles in the refrigerator.

(5) Human serum obtained under sterile conditions is stored in McCartney bottles in the refrigerator. If possible serum older than 28 days should not be used.

Procedure.-Two ml. of sternal marrow are injected into $18-20 \mathrm{ml}$. of heparin-Ringer solution heated to $30-36^{\circ} \mathrm{C}$. by piercing the rubber disc through the perforation in the cap. Within one hour the bottles are centrifuged for 10 minutes at 1,500 r.p.m. The supernatant fluid is sucked off with a syringe. The suction is facilitated by employing an air vent. Five to $10 \mathrm{ml}$. of Gey's solution at $30-36^{\circ} \mathrm{C}$. are added to the cell suspension and the contents mixed thoroughly by pumping the fluid in and out with a syringe for at least three minutes. Less thorough mixing results in the cells clumping. One drop of the marrow suspension is sucked off and a preliminary count of the nucleated cells is made, using ordinary leucocyte-diluting fluid. The count should fall between 15,000 and 50,000 cells per c.mm. If it exceeds this range, adjustment is made by adding more Gey's fluid. To prepare the final culture medium it is now calculated how much serum and Gey's solution must be added to the suspension to get a mixture containing the desired concentration of serum (this can vary from 20 to $95 \%$, depending on the design of the experiment) and approximately 2,000-4,000 nucleated cells per c.mm. If, for example, the suspension contains 30,000 nucleated cells per c.mm., and an $80 \%$ serum concentration in the medium has been decided upon, 1 in 10 dilution would be suitable. Hence $16 \mathrm{ml}$. of serum are mixed with $2 \mathrm{ml}$. of Gey solution in a syringe and $2 \mathrm{ml}$. of the suspension are sucked into the mixture.

If it is desired to investigate the influence of special substances, these should be dissolved or suspended in physiological saline in such concentration that not more than $0.10 \mathrm{ml}$. of the preparation has to be added to each $3 \mathrm{ml}$. of medium, i.e. $0.03 \mathrm{ml} . / \mathrm{ml}$. medium.

After careful mixing of the final culture in the syringe by shaking for two or three minutes a volume of $3 \mathrm{ml}$. is injected into each of a number of McCartney bottles. Sufficient fluid must be left in the syringe to allow an accurate total cell count to be made. This represents the initial or "start" count. The initial differential count is done on the slides prepared during the original sternal puncture. It was found that this 
count does not differ significantly from differential counts made on smears from the cultures at $\mathbf{0}$ hours. It is considered necessary to count at least 500 nucleated red cells or, better still, 1,000 .

The cultures are kept in an incubator at $37^{\circ} \mathrm{C}$. and at desired intervals a bottle is taken out, the contents mixed thoroughly for three or four minutes, and an accurate total count of the nucleated cells made as before. The bottle is then centrifuged at 1,500 r.p.m. for 10 minutes and the supernatant fluid discarded, one or two drops being left to ensure a homogeneous mixture of the cells. Slides are now prepared and differential counts done as before. It may occasionally be advisable to open two bottles at one time as a control of the uniform behaviour of the cultures.

The marrow from a sternal puncture is best obtained by sudden forceful suction. A more cellular marrow less diluted with peripheral blood results from this method.

In experiments involving the culture of megaloblastic marrow in pernicious anaemia serum the serum should be taken from a different subject, since the patient's own serum may ripen megaloblasts to a greater extent than serum from another patient. This has been observed previously by Osgood and Brownlee (1937).

The method can naturally be adapted to the use of other media such as normal, dried, and reconstituted plasma. It has been observed that in normal plasma maturation and degeneration of the cells proceeds faster. Dried and reconstituted plasma lacks factors necessary for normal maturation, and in old cultures this plasma was sometimes found to be toxic. When serum is used the bone marrow cultures may be kept alive for three to five days and leukaemic cells for 10 to 14 days.

Changing the medium, which might theoretically prolong the life of the cultures, cannot be carried out for the following reasons. (1) It is impossible to replace exactly the amount of old medium drawn off. The statistical significance in the total counts is therefore impaired. (2) The new medium added will always be of different composition from the old fluid drawn off. This sudden change of medium is noxious to the cells. (3) Finally, it is doubtful whether more useful information can be obtained by keeping the cells alive for longer periods than are already assured by the simple method described above.

If possible it is advisable to employ serum of the same blood group as that of the patient from whom the culture is taken. Although the white cells are not affected by incompatible serum, homogeneous suspensions are difficult to obtain and the differential counts suffer accordingly.

The value of the method depends largely on the accuracy of the total counts. As many as possible of the components of error usually associated with the white cell count have therefore been eliminated by using the same pipettes and counting chambers throughout. The error due to filling the pipettes can be reduced by using two to four pipettes for each count. In these circumstances, if all counts are made by one observer, the error is found to approach that of the Poisson distribution. Thus for counts of 500 cells the coefficient of variation is about $5 \%$ and for 1,000 cells about $3 \%$.

Silicone Coating. - It is known that white cells can "stick" to glass surfaces. Since large numbers of cells adhering to the surface of the culture bottles would modify the culture results, this problem needed investigation.

A grease-free coverslip was laid on the bottom of several culture bottles, and was removed, washed in running tap water, and stained at the same time as the smears and total counts were made. A large number of cells were found to be adhering firmly to the coverslip; the cells involved were always predominantly myeloid and monocytoid. No adhesion of nucleated red cells was ever seen. The density of the deposit was about 300,000 per sq. $\mathrm{cm}$. 
Parallel cultures were set up with ordinary and silicone-coated culture bottles. The results were as follows :

Total Nucleated Cell Counts

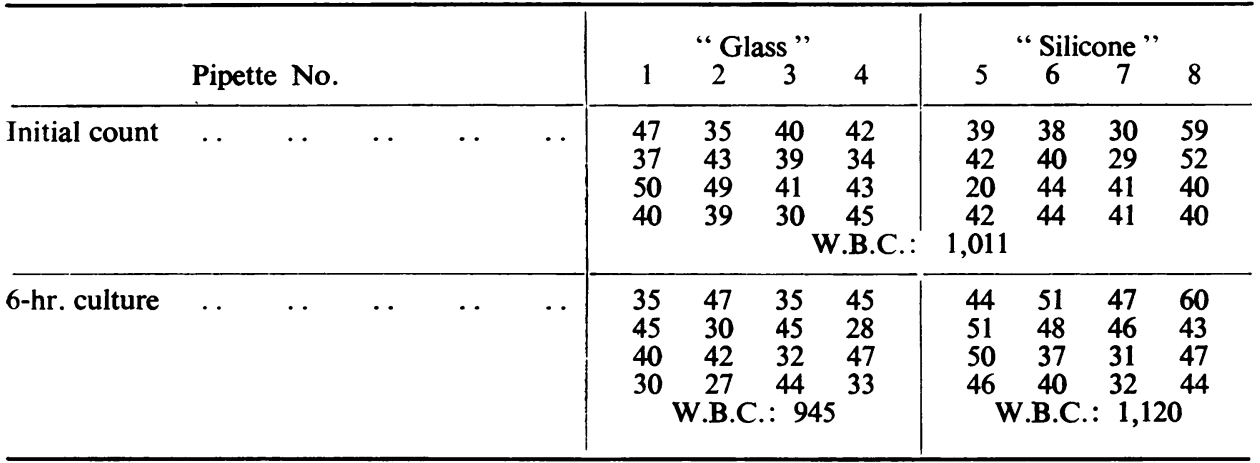

Differential Counts on 200 Cells Each

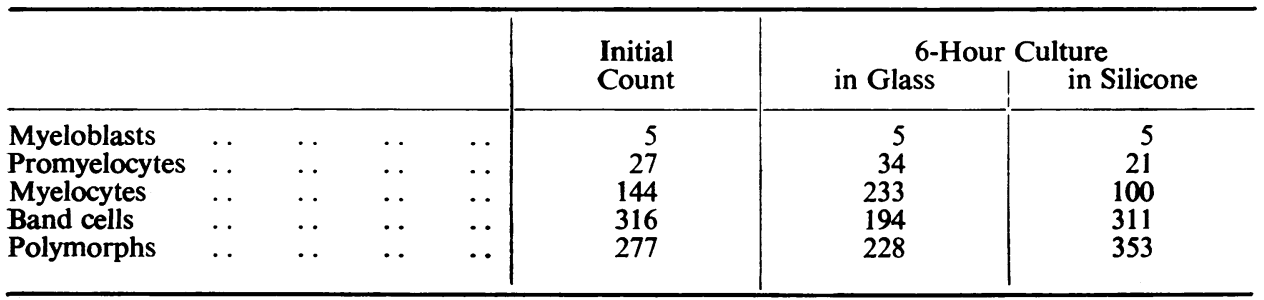

These results indicated that, although the differential distribution of nucleated red cells is not altered by cells adhering to the surface of the culture bottles, the white cell distribution might be influenced by it. The cultures where total nucleated cell counts were performed were, therefore, cultured in silicone-coated bottles.

It should be noted that all the silicone must be hydrolysed to the glass surface, free silicone being very toxic for the cells.

Nomenclature.-The following nomenclature is used.

Pronormoblasts.- The first recognizable nucleated red cells. Large, strongly basophilic cytoplasm, fine nuclear structure, numerous nucleoli.

Basophil Normoblasts.-Smaller in size than pronormoblasts, nuclear structure coarser, fewer nucleoli.

Polychromatic Normoblasts. - Various degree of haemoglobination in the cytoplasm. Nucleus gradually changing from "finely lumpy" to pyknotic. No nucleoli.

Orthochromatic Normoblasts.--Usually pyknotic nuclei. No traces of basophilia in the cytoplasm ; it has the colour of the ripe erythrocyte (and not the polychromatic erythrocyte !).

Megaloblasts.-The cells which are characteristic for pernicious anaemia in relapse and are never found in normal marrows or in marrows other than liver factor or folic acid deficiency (Ehrlich and Lazarus, 1898 ; Naegeli, 1931 ; Jones, 1943, 1947, 1948 ; Dacie and White, 1949). 


\section{Culture of Normoblastic Marrows in vitro}

Preliminary experiments showed that with the marrow culture technique human bone marrows could be kept alive for several days. Before proceeding to the culture of megaloblastic bone marrows in vitro it was essential to establish how far the behaviour of human bone marrow in culture approaches that observed in vivo. For this purpose, studies were made on a series of 23 normal marrows from normal subjects cultured in normal serum.

The results are represented in Tables I and II and Figs. 1, 2, and 3.

The percentage of the early red cell precursors (pronormoblasts and basophilic normoblasts) which initially represent one-fourth to one-fifth of the nucleated red

TABLE I

CUltures of Normoblasts in Normal Sera

\begin{tabular}{|c|c|c|c|c|c|c|c|c|c|c|c|c|}
\hline \multirow[b]{2}{*}{$\begin{array}{c}\text { Experiment } \\
\text { No. }\end{array}$} & \multicolumn{3}{|c|}{ Initial Counts* } & \multicolumn{3}{|c|}{ 6-Hr. Cultures } & \multicolumn{3}{|c|}{ 24-Hr. Cultures } & \multicolumn{3}{|c|}{ 48-Hr. Cultures } \\
\hline & 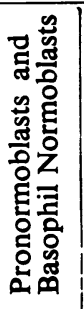 & 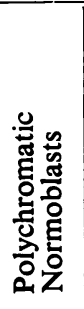 & 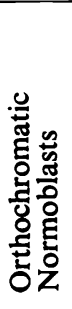 & 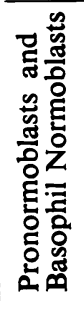 & 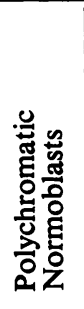 & 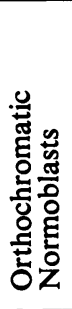 & 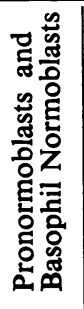 & 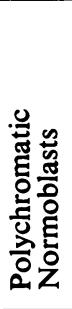 & 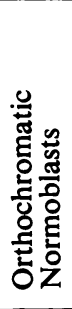 & 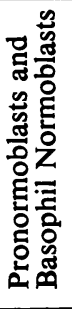 & 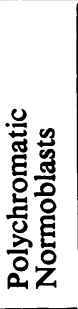 & 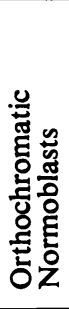 \\
\hline 1 & $24 \cdot 0$ & $75 \cdot 0$ & $1 \cdot 0$ & & & & $\begin{array}{l}15 \cdot 0 \\
12.0\end{array}$ & $64 \cdot 0$ & $\begin{array}{l}21 \cdot 0 \\
28.0\end{array}$ & $9 \cdot 0$ & $61 \cdot 0$ & 30.0 \\
\hline $\begin{array}{r}5 \\
6 \\
7 \\
8 \\
11 \\
28 \\
29 \\
31\end{array}$ & $\begin{array}{r}26.0 \\
24.0 \\
8.0 \\
19.5 \\
36.0 \\
40.0 \\
25.7 \\
25.6\end{array}$ & $\begin{array}{l}68 \cdot 0 \\
72 \cdot 0 \\
83 \cdot 0 \\
57 \cdot 0 \\
58 \cdot 0 \\
57 \cdot 2 \\
74 \cdot 3 \\
74 \cdot 2\end{array}$ & $\begin{array}{r}6.0 \\
4.0 \\
9.0 \\
23.5 \\
6.0 \\
2.8 \\
0.0 \\
0.2\end{array}$ & $24 \cdot 0$ & $66 \cdot 0$ & $10 \cdot 0$ & $\begin{array}{r}15.0 \\
7.0 \\
6.5 \\
25.0\end{array}$ & $\begin{array}{r}67 \cdot 0 \\
68.0 \\
15 \cdot 0 \\
61 \cdot 1\end{array}$ & $\begin{array}{r}18.0 \\
25.0 \\
78.5 \\
13.9\end{array}$ & $\begin{array}{r}6.0 \\
14.0 \\
3.0 \\
5.0 \\
15.0 \\
12.9 \\
4.9 \\
7.0\end{array}$ & $\begin{array}{l}60.0 \\
70.0 \\
50.0 \\
22.0 \\
50.0 \\
58.1 \\
27.7 \\
73.2\end{array}$ & $\begin{array}{l}34.0 \\
16.0 \\
47.0 \\
73.0 \\
35.0 \\
29 \cdot 0 \\
67.4 \\
19 \cdot 8\end{array}$ \\
\hline 34 & 46.9 & 35.4 & $17 \cdot 7$ & $12 \cdot 2$ & $49 \cdot 4$ & $38 \cdot 4$ & $13 \cdot 6$ & $25 \cdot 2$ & $61 \cdot 2$ & & & \\
\hline 35 & $26 \cdot 3$ & $68 \cdot 4$ & $\begin{array}{l}5 \cdot 3 \\
5 \cdot 5\end{array}$ & & & & 20.0 & $60 \cdot 0$ & $20 \cdot 0$ & $6 \cdot 3$ & $49 \cdot 4$ & $44 \cdot 3$ \\
\hline 43 & $\begin{array}{l}31 \cdot 5 \\
17 \cdot 8\end{array}$ & $\begin{array}{l}63 . \\
64\end{array}$ & $\begin{array}{r}5 \cdot 5 \\
17 \cdot 8\end{array}$ & 13.0 & $67 \cdot 0$ & 20.0 & $\begin{array}{l}15.2 \\
13.0\end{array}$ & $\begin{array}{l}71 \cdot 1 \\
43.5\end{array}$ & $\begin{array}{l}13.1 \\
43 \cdot 5\end{array}$ & 1.0 & 10.0 & 2300 \\
\hline 46 & 21.6 & 64 . & 13.5 & 10.8 & $76 \cdot 1$ & $13 \cdot 1$ & $6 \cdot 2$ & $81 \cdot 4$ & 12.4 & 0.0 & 59.0 & 41 . \\
\hline 48 & $21 \cdot 0$ & 68.5 & 10.5 & 17.0 & $65 \cdot 4$ & $17 \cdot 6$ & $9 \cdot 5$ & 69.9 & $20 \cdot 6$ & 0.0 & $67 \cdot 0$ & 33 \\
\hline 49 & $23 \cdot 8$ & $73 \cdot 3$ & 2.9 & $22 \cdot 1$ & 73.9 & 4.0 & $5 \cdot 3$ & 68.5 & $26 \cdot 2$ & 0.0 & $41 \cdot 2$ & $58 \cdot 8$ \\
\hline 52 & $20 \cdot 0$ & $80 \cdot($ & 0.0 & $9 \cdot 6$ & 65.4 & 25 & 3.0 & $58 \cdot 0$ & $39 \cdot 0$ & & & \\
\hline 54 & $14 \cdot 4$ & 85 & 0.0 & $21 \cdot 6$ & $72 \cdot 2$ & $6 \cdot 2$ & 11.0 & 82.2 & $6 \cdot 8$ & 0.0 & 75.0 & 25.0 \\
\hline 57 & 18.2 & 81. & 0.0 & & & & 15 & 72 & 12. & 4.5 & $42 \cdot 2$ & $53 \cdot 3$ \\
\hline 64 & 15 & 80 & 4. & & & & 15.9 & $57 \cdot 9$ & $26 \cdot 2$ & $12 \cdot 0$ & $45 \cdot 1$ & 42.9 \\
\hline $\begin{array}{l}71 \\
73\end{array}$ & $\begin{array}{l}13 \cdot 0 \\
18 \cdot 0\end{array}$ & $\begin{array}{l}86 \cdot 0 \\
73 \cdot 0\end{array}$ & $\begin{array}{l}1.0 \\
9.0\end{array}$ & & & & & & & $\begin{array}{l}2 \cdot 0 \\
7.0\end{array}$ & $\begin{array}{l}48 \cdot 0 \\
55 \cdot 0\end{array}$ & $\begin{array}{l}50.0 \\
38.0\end{array}$ \\
\hline 75 & $17 \cdot 0$ & 81.0 & 2.0 & & & & & & & $\begin{array}{r}11.0 \\
0.0\end{array}$ & $\begin{array}{l}49 \cdot 0 \\
57 \cdot 0\end{array}$ & $\begin{array}{l}40.0 \\
43.0\end{array}$ \\
\hline & & & & & & & & & & $1 \cdot 0$ & $26 \cdot 0$ & $73 \cdot 0$ \\
\hline leans & $23 \cdot 2$ & $70 \cdot 6$ & $6 \cdot 2$ & $16 \cdot 3$ & $67 \cdot 0$ & $16 \cdot 7$ & $12 \cdot 3$ & $60 \cdot 3$ & $27 \cdot 4$ & $5 \cdot 7$ & $52 \cdot 2$ & $42 \cdot 1$ \\
\hline
\end{tabular}

* Distribution of nucleated red cells in percentages. 
cells and show only few mitotic figures decreases in culture (Table I and Fig. 1). The polychromatic normoblasts, initially about $70 \%$ of all the nucleated red cells, show numerous mitotic figures, but their number also decreases during 48 hours' culture. The number of orthochromatic normoblasts, on the other hand, which normally represent less than $10 \%$ of all the nucleated red cells, increases in the cultures greatl!.

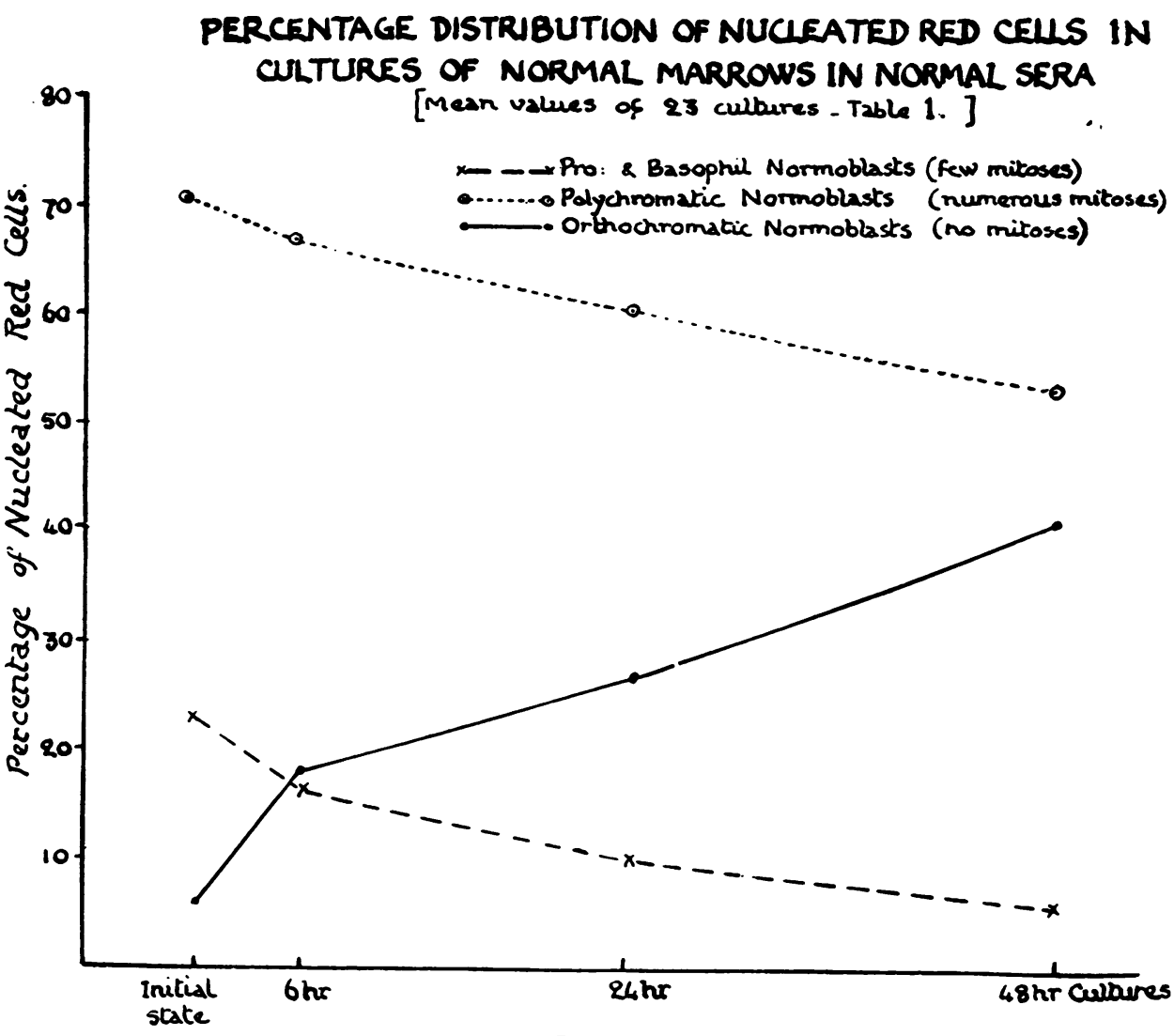

FIG. 1

No mitotic figures were seen in orthochromatic normoblasts, therefore their increase in number was attributed to a process of maturation from the earlier nucleated red cell forms. The maturation of polychromatic normoblasts not only gives rise to orthochromatic normoblasts but also to reticulocytes (polychromatic erythrocytes).

These results are confirmed by absolute nucleated cell counts also (Table II and Fig. 2) and show that maturation from earlier cell forms to later cell forms, similar to that observed in vivo, occurs in the cultures.

The appearance of mitotic figures on a slide is not necessarily a sign of multiplication, and to demonstrate the dual process of multiplication and maturation in the cultures an experiment was planned where the cell multiplication was inhibited by colchicine. Fig. 3 shows the results expressed in absolute numbers. Colchicine 
in $1: 10^{6}$ concentration by inhibiting mitosis abolishes the increase of polychromatic normoblasts during the first six hours of the culture as well as the gradual increase in number of orthochromatic normoblasts. It produces also a sharper fall in the early red cell precursors. These results indicate that both cell proliferation and

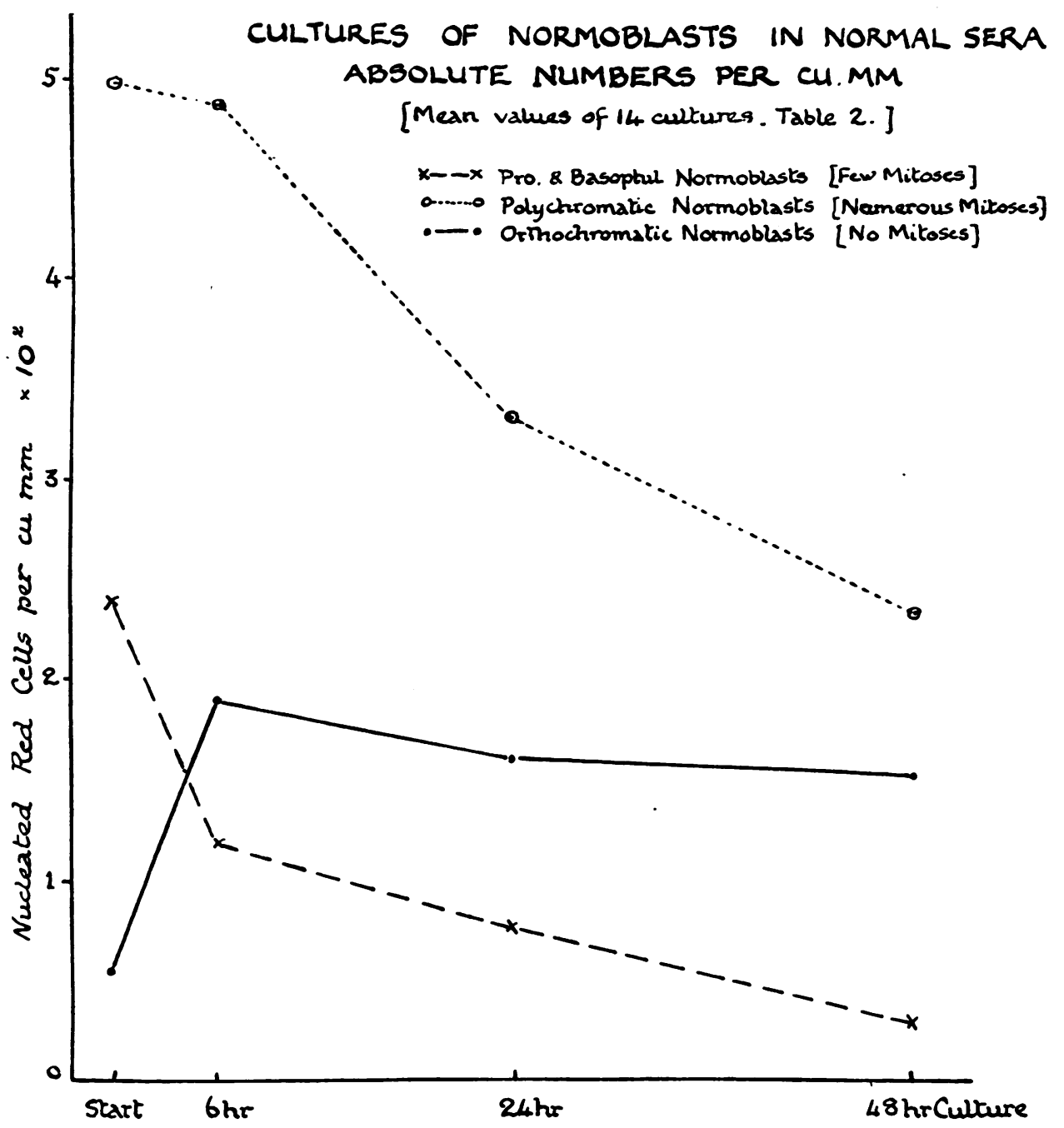

FIG. 2

differentiation occur in the cultures and that the increase in number of orthochromatic normoblasts is due to multiplication and maturation of the earlier cell forms. This concentration of colchicine was found not to be toxic for the cells, no increase in "cell death" (smear cells) was observed, and no appreciable effect on cell maturation was noted. 
TABLE II

Cultures of Normoblasts in Normal Sera

\begin{tabular}{|c|c|c|c|c|c|c|c|c|c|c|c|c|}
\hline \multirow[b]{2}{*}{$\begin{array}{l}\text { Experiment } \\
\text { No. }\end{array}$} & \multicolumn{3}{|c|}{ Initial Counts* } & \multicolumn{3}{|c|}{ 6-Hr. Cultures } & \multicolumn{3}{|c|}{ 24-Hr. Cultures } & \multicolumn{3}{|c|}{ 48-Hr. Cultures } \\
\hline & 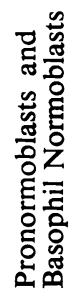 & 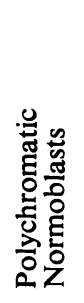 & 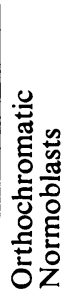 & 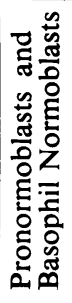 & 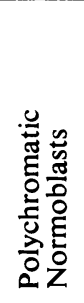 & 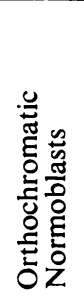 & 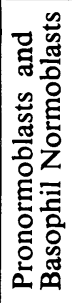 & 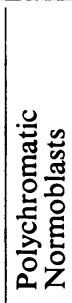 & 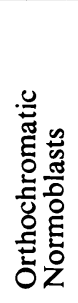 & 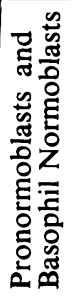 & 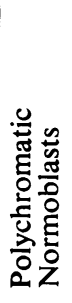 & 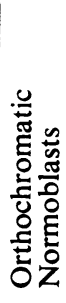 \\
\hline $\begin{array}{l}28 \\
29 \\
31\end{array}$ & $\begin{array}{l}448 \\
180 \\
196\end{array}$ & $\begin{array}{l}640 \\
520 \\
570\end{array}$ & $\begin{array}{r}32 \\
0 \\
2\end{array}$ & & & & 279 & 682 & 155 & $\begin{array}{r}120 \\
20 \\
36\end{array}$ & $\begin{array}{l}540 \\
113 \\
375\end{array}$ & $\begin{array}{l}270 \\
274 \\
101\end{array}$ \\
\hline 34 & 1,384 & 1,044 & 522 & 352 & 1,434 & 1,115 & 240 & 448 & 1,088 & & & \\
\hline 35 & 20 & 5 & 40 & & & & 80 & 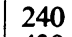 & & 16 & 125 & 112 \\
\hline 4 & 18 & 3 & 33 & & & & 90 & 43 & 7 & 28 & 280 & 92 \\
\hline 45 & 50 & 18 & 50 & 40 & 200 & 60 & 30 & 100 & 100 & & & \\
\hline 46 & 12 & 36 & 75 & 87 & 6 & 10 & 32 & 41 & 64 & 0 & 165 & 115 \\
\hline 4 & 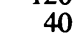 & 13 & 20 & 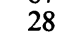 & 1 & 2 & 6 & 4 & 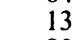 & 0 & 20 & 10 \\
\hline 49 & 13 & 40 & 16 & 90 & 30 & 16 & 16 & 21 & 8 & 0 & 80 & 114 \\
\hline 52 & 2 & 8 & 0 & 10 & & 2 & 5 & 8 & 5 & & & \\
\hline 54 & 130 & 77 & 0 & 210 & 700 & 60 & 80 & 600 & 50 & 0 & 450 & 150 \\
\hline 57 & 180 & 810 & 0 & & & & 100 & 4 & 80 & 20 & 190 & 240 \\
\hline 64 & & 52 & 28 & & & & 75 & 274 & 124 & 56 & 210 & 200 \\
\hline $\begin{array}{l}\text { Means ... } \\
\text { Total of means }\end{array}$ & 240 & $\begin{array}{l}498 \\
796\end{array}$ & 58 & 117 & $\begin{array}{l}489 \\
793\end{array}$ & 187 & 78 & $\begin{array}{l}333 \\
575\end{array}$ & 164 & 27 & $\begin{array}{l}232 \\
411\end{array}$ & 152 \\
\hline
\end{tabular}

* Absolute numbers per c.mm.

The changes in nucleated red cells only are dealt with in this paper since the current problems were concerned with erythropoiesis. No relevant changes were noted in the white cell series throughout the experiments. The white cells survive much longer in cultures than the red cells and maturation from early cell forms to late cell forms could be readily observed in all the cultures of both normoblastic and megaloblastic marrows.

In contrast to white cells nucleated red cells do not survive for many days in culture. After 48 hours most cultures show increasing degenerative changes. Less than one-half of the cultures showed a satisfactory level and morphology of nucleated red cells at 72 hours and only very occasional cultures at 96 hours. Because of this, most observations have been made in 24- to 48-hour cultures.

The conclusion drawn from these observations was that human bone marrows cultured in vitro approach the behaviour of the bone marrow observed in vivo. Two differences from the in vivo conditions, however, should be noted. The first is the rapid loss of proliferative power. After the first six to eight hours of culture the multiplication does not keep in step with the differentiation, resulting in a gradual accumulation of the late cell forms. This could be explained by a rapid exhaustion from the culture medium of a factor, or factors, necessary for cell proliferation, or by the absence in vitro of a cell type (? reticulum cell) responsible for the con- 
THE EFFECT OF $1: 10^{6}$ COLCHICINE ON CULTURE OF NORMOBLASTS IN NORMAL SERUM

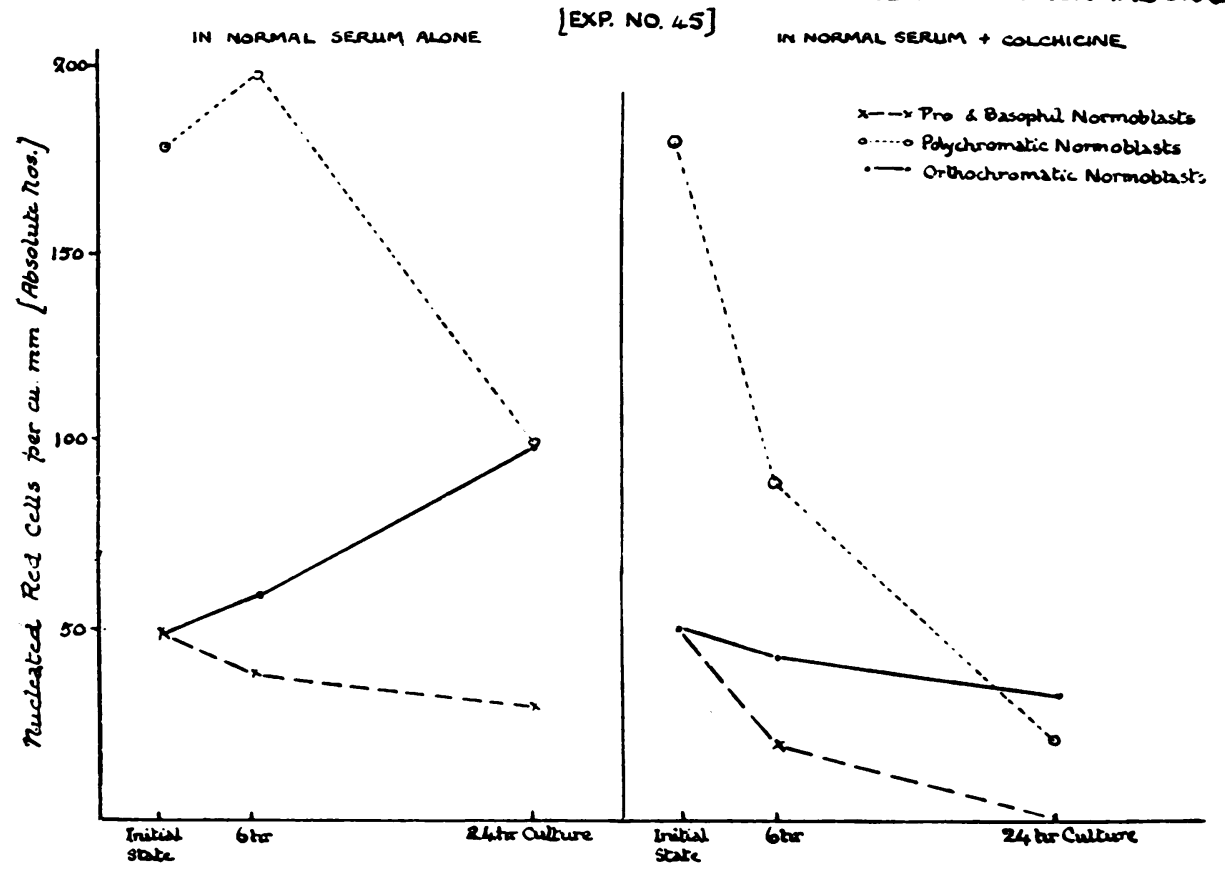

FIG. 3

tinuous production of early cell forms. Some evidence for the former theory is that embryo extract is necessary for maintaining multiplication in all tissue cultures. The use of such an extract with its many unknown factors was considered undesirable in these experiments.

The second difference in cultures from the in vivo behaviour of the normal bone marrow is the gradual accumulation of orthochromatic normoblasts. In normal human bone marrows these cells practically never exceed $10 \%$ of all the nucleated red cells. Indeed, an increase in their number is usually a sign of some disorder in red cell maturation. No satisfactory explanation can be given for their increase in number in vitro.

No tissue culture conditions are known which are identical with in vivo conditions, but it is reasonable to assume that what a cell or cell type can do in vitro it might also do in vivo. As the behaviour of 23 normal human bone marrows cultured in normal serum in vitro closely approached the behaviour of normal human bone marrows in vivo, it was concluded that the culture technique could yield useful information on the influence of different substances on erythropoiesis.

\section{Culture of Megaloblastic Marrows in vitro}

After the behaviour of normal human bone marrows in vitro had been assessed and the method of culture had been found satisfactory, similar studies on megalo- 
blastic marrows were made. In all 25 megaloblastic marrows were cultured in a medium containing $35-80 \%$ serum (from normal subjects, or from patients with untreated pernicious anaemia) and $20-65 \%$ Gey or Ringer's solution.

The results presented in Table III indicate a considerable decrease in the percentage of the megaloblasts when cultured in normal serum as compared with the initial state. This was not unexpected as it was assumed that normal serum contains the factors necessary to normal cell maturation. The decrease, however, could have

TABLE III

Cultures of Megaloblasts in Normal and Pernicious Anaemia Sera*

\begin{tabular}{|c|c|c|}
\hline Experiment No. & Initial Count & $\begin{array}{c}\text { Cultures in Normal Serum } \\
\text { (48 Hours) }\end{array}$ \\
\hline $\begin{array}{l}\text { B3 } \\
\text { B4 } \\
\text { B5 } \\
\text { B6a } \\
\text { B6b } \\
\text { B8 } \\
\text { B11 } \\
\text { B13 } \\
\text { B15 } \\
\text { B16 } \\
\text { B19 } \\
\text { B22 } \\
\text { B23 } \\
\text { B27 } \\
\text { B30 } \\
3 \\
42 \\
59 \\
65 \\
76\end{array}$ & $\begin{array}{r}30 \cdot 0 \\
23 \cdot 5 \\
41 \cdot 5 \\
79 \cdot 0 \\
79 \cdot 0 \\
18 \cdot 5 \\
14 \cdot 0 \\
32 \cdot 5 \\
23 \cdot 0 \\
35 \cdot 0 \\
29 \cdot 0 \\
29 \cdot 5 \\
9.5 \\
11 \cdot 5 \\
85 \cdot 0 \\
31 \cdot 0 \\
60.0 \\
25 \cdot 2 \\
48 \cdot 0 \\
35 \cdot 0\end{array}$ & $\begin{array}{r}15.0 \\
3.5 \\
9.5 \\
12.5 \\
0.5 \\
1.5 \\
1.0 \\
4.5 \\
17.0 \\
7.0 \\
0.5 \\
2.5 \\
0.0 \\
1.0 \\
17.0 \\
19.0 \\
18.0 \\
0.0 \\
32.0 \\
13.0\end{array}$ \\
\hline Means & $37 \cdot 0$ & $\begin{array}{c}8 \cdot 8 \\
(74 \cdot 7 \% \text { drop })\end{array}$ \\
\hline
\end{tabular}

*Megaloblasts per 100 nucleated red cells. $35 \%$ serum + $65 \%$ Ringer's solution

resulted from elective dying off of megaloblasts, from maturation of megaloblasts to megalocytes, or from conversion of megaloblasts to other cell forms. The examination of the cultures has shown that in the 48-hour cultures there was no increase in the number of smear cells, and no degenerative changes among the cells, but there were numerous transitional forms which suggested a transformation of megaloblasts into the normoblastic type of cell.

In experiments where absolute differential counts were made on the nucleated red cells it has been found that decrease in the number of megaloblasts in culture is accompanied by an increase in the number of normoblasts. This is clearly illustrated by a culture of a megaloblastic marrow in normal serum (Fig. 4). Ten similar experiments, included in Table IV and Fig. 5, demonstrate the same reciprocal changes. Here again the results are expressed in absolute numbers and show that whenever megaloblasts are cultured in a medium where a decrease in the numbers of 


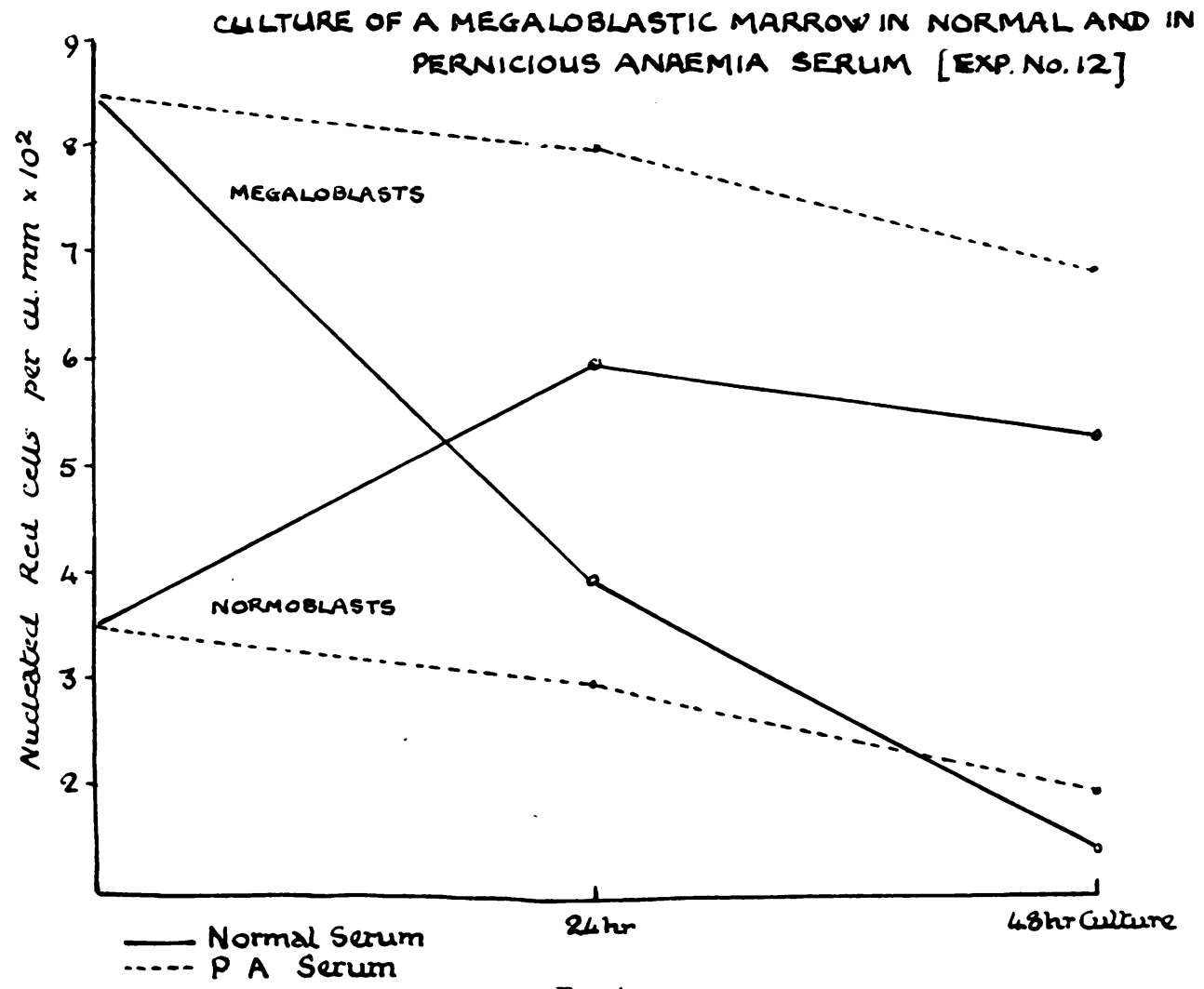

Fig. 4

megaloblasts not due to degenerative changes is noted, it is followed by a corresponding rise in normoblasts.

Fig. 6 illustrates this phenomenon further. Normoblasts from normal marrows when cultured in normal serum mature normally and their number gradually decreases during the culture. When megaloblastic marrows are cultured in normal serum the ripening of megaloblasts into normoblasts is such that the maturation of normoblasts is masked by it.

Further, that this increase in normoblasts is not an arrest of maturation but maturation to erythrocytes is shown by experiments in which reticulocytes were counted in cultures (Table $\mathrm{V}$ and Fig. 7). Reticulocytes ripen in vitro to erythrocytes and in cultures of peripheral blood the reticulocyte count decreases accordingly ; but when megaloblastic marrows are cultured in a medium in which large numbers of megaloblasts are transformed to normoblasts there is an increase in reticulocytes, i.e. the ripening of reticulocytes is masked by the production of new reticulocytes. This increase in reticulocytes is statistically significant.

These results indicate that when megaloblasts are cultured in normal serum their number decreases, this decrease being due to the transformation of megaloblasts to 
TABLE IV

Cultures of Megaloblastic Marrows in Normal and in Pernicious anaemia Sera

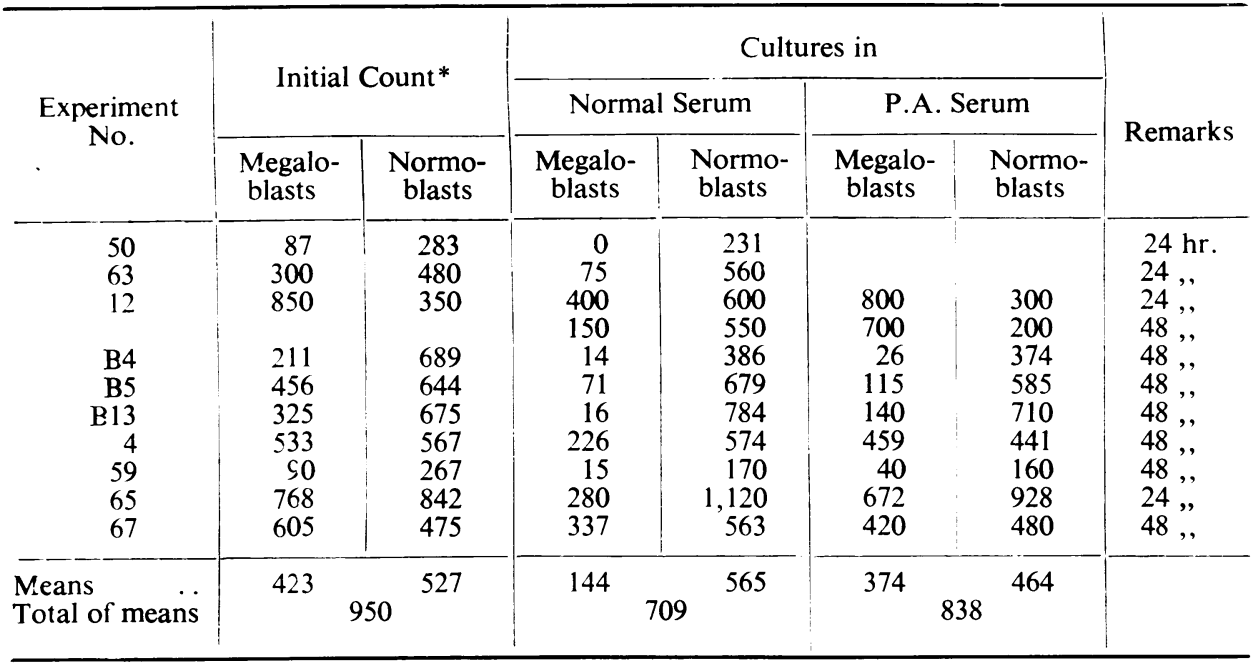

* Absolute numbers per c.mm.

TABLE V

RETICULOCYTE EXPERIMENTS

\begin{tabular}{|c|c|c|c|c|c|c|}
\hline \multirow{2}{*}{ Source of Reticulocytes } & \multirow{2}{*}{$\begin{array}{c}\text { Experi- } \\
\text { ment No.* }\end{array}$} & \multirow{2}{*}{ Start $\dagger$} & \multicolumn{4}{|c|}{ Cultures } \\
\hline & & & $6-\mathrm{Hr}$ & 12-Hr. & $24-\mathrm{Hr}$ & 48-Hr. \\
\hline \multirow[t]{2}{*}{ Peripheral blood } & $\begin{array}{l}\text { B9 } \\
\text { B10 } \\
\text { B12 } \\
\text { B14 } \\
\text { B17 }\end{array}$ & $\begin{array}{r}2 \cdot 1 \\
7 \cdot 7 \\
12 \cdot 0 \\
11 \cdot 3 \\
21 \cdot 8\end{array}$ & $\begin{array}{r}2.0 \\
7.5 \\
13.6 \\
13.0 \\
22.7\end{array}$ & $\begin{array}{r}3.0 \\
5.0 \\
11.0 \\
12.0 \\
23.5\end{array}$ & $\begin{array}{r}1.3 \\
6.0 \\
10.6 \\
8.4 \\
20.7\end{array}$ & $\begin{array}{r}1 \cdot 0 \\
2 \cdot 5 \\
6 \cdot 3 \\
3 \cdot 3 \\
16 \cdot 4\end{array}$ \\
\hline & Mean & $11 \cdot 0$ & $11 \cdot 8$ & $10 \cdot 9$ & $9 \cdot 4$ & $5 \cdot 9$ \\
\hline \multirow[t]{2}{*}{$\begin{array}{l}\text { Pernicious anaemia marrows in per- } \\
\text { nicious anaemia sera }\end{array}$} & $\begin{array}{l}\text { B10 } \\
\text { B12 } \\
\text { B14 } \\
\text { B17 }\end{array}$ & $\begin{array}{r}9.0 \\
16.3 \\
11.6 \\
12.0\end{array}$ & $\begin{array}{r}9 \cdot 1 \\
11 \cdot 5 \\
12 \cdot 3 \\
10 \cdot 1\end{array}$ & $\begin{array}{r}9 \cdot 9 \\
12 \cdot 6 \\
11 \cdot 5 \\
12 \cdot 3\end{array}$ & $\begin{array}{r}11 \cdot 6 \\
14 \cdot 2 \\
9 \cdot 0 \\
10 \cdot 0\end{array}$ & $\begin{array}{l}11.0 \\
13.0 \\
10.9 \\
11.9\end{array}$ \\
\hline & Mean & $12 \cdot 2$ & $10 \cdot 8$ & $11 \cdot 6$ & $11 \cdot 2$ & $11 \cdot 7$ \\
\hline \multirow[t]{2}{*}{$\begin{array}{l}\text { Pernicious anaemia marrows in normal } \\
\text { sera }\end{array}$} & $\begin{array}{l}\text { B10 } \\
\text { B12 } \\
\text { B14 } \\
\text { B17 }\end{array}$ & $\begin{array}{r}9 \cdot 0 \\
16 \cdot 3 \\
11 \cdot 6 \\
12 \cdot 0\end{array}$ & $\begin{array}{r}8 \cdot 0 \\
12 \cdot 8 \\
13 \cdot 9 \\
12 \cdot 9\end{array}$ & $\begin{array}{r}9 \cdot 0 \\
17 \cdot 9 \\
12 \cdot 2 \\
15 \cdot 3\end{array}$ & $\begin{array}{l}11.8 \\
18.7 \\
15.0 \\
13.0\end{array}$ & $\begin{array}{l}10 \cdot 1 \\
21 \cdot 0 \\
17 \cdot 5 \\
18 \cdot 5\end{array}$ \\
\hline & Mean & $12 \cdot 2$ & $11 \cdot 9$ & $13 \cdot 6$ & $14 \cdot 6$ & $16 \cdot 8$ \\
\hline
\end{tabular}

* 1,000 R.B.C.s counted.

$\dagger$ Reticulocytes per 100 red cells 


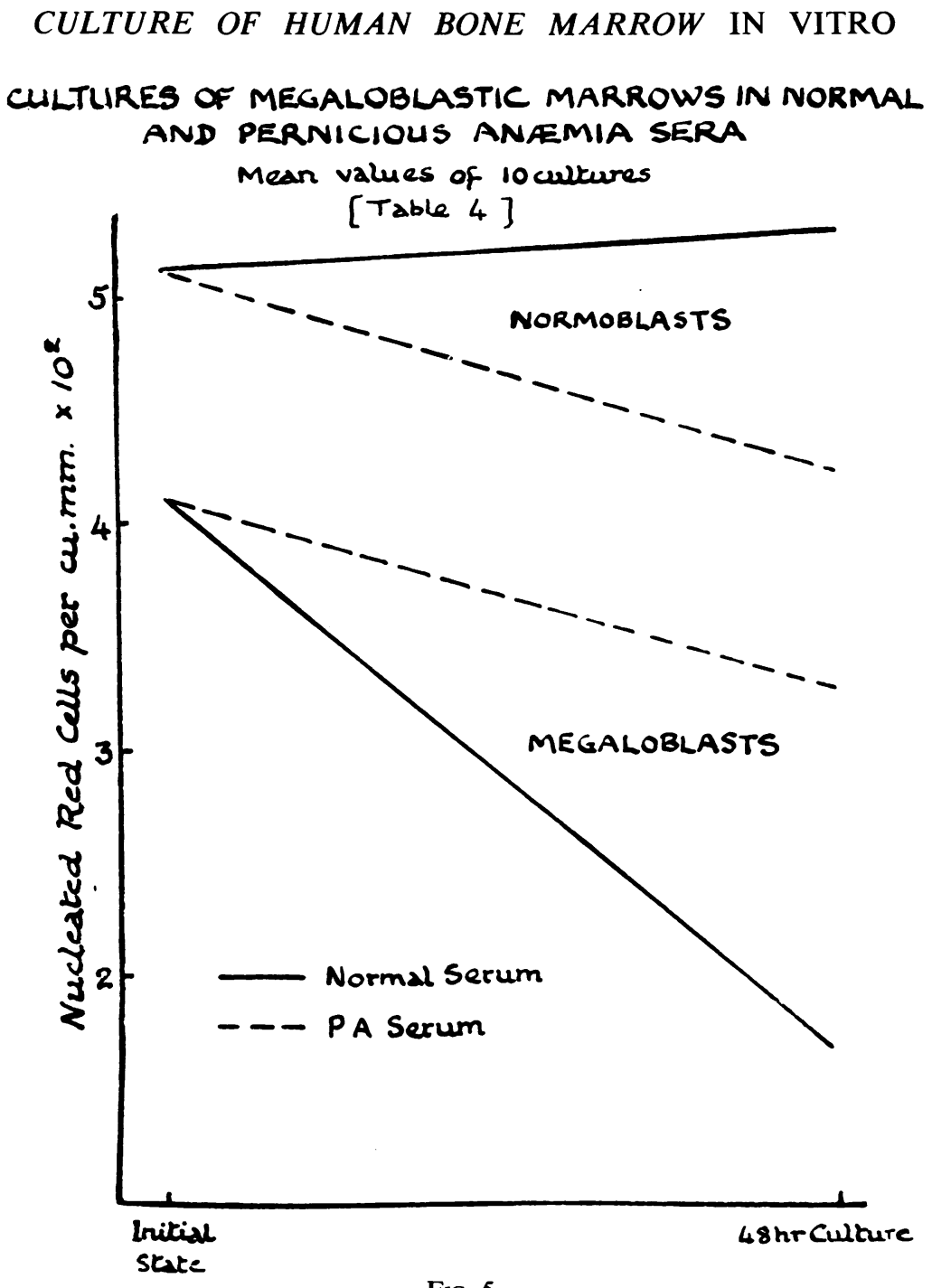

normoblasts. This process may be so extensive as to mask the maturation of normoblasts to erythrocytes, and instead of a decrease in the numbers of normoblasts (which occurs when normoblastic marrows are cultured in normal serum) their number actually increases.

\section{Transformation of Normoblasts into Megaloblasts}

Experiments in which culture in undiluted pernicious anaemia serum caused transformation of originally normoblastic into megaloblastic marrows have been reported in a previous communication (Lajtha, 1950) and have been confirmed independently by Thompson (1951). It should be emphasized here that it was found necessary to keep the cultures incubated for 72 hours, since not all cultures 
THE BEHAVIOUR OF NORMOBLASTS FROM NORMAL MARROWS IN NORMAL SERA COMPARED WITH NORMOBLASTS IROM MEGALOBLASTIC MARROWS IN NORMAL AND P.A. SERA.

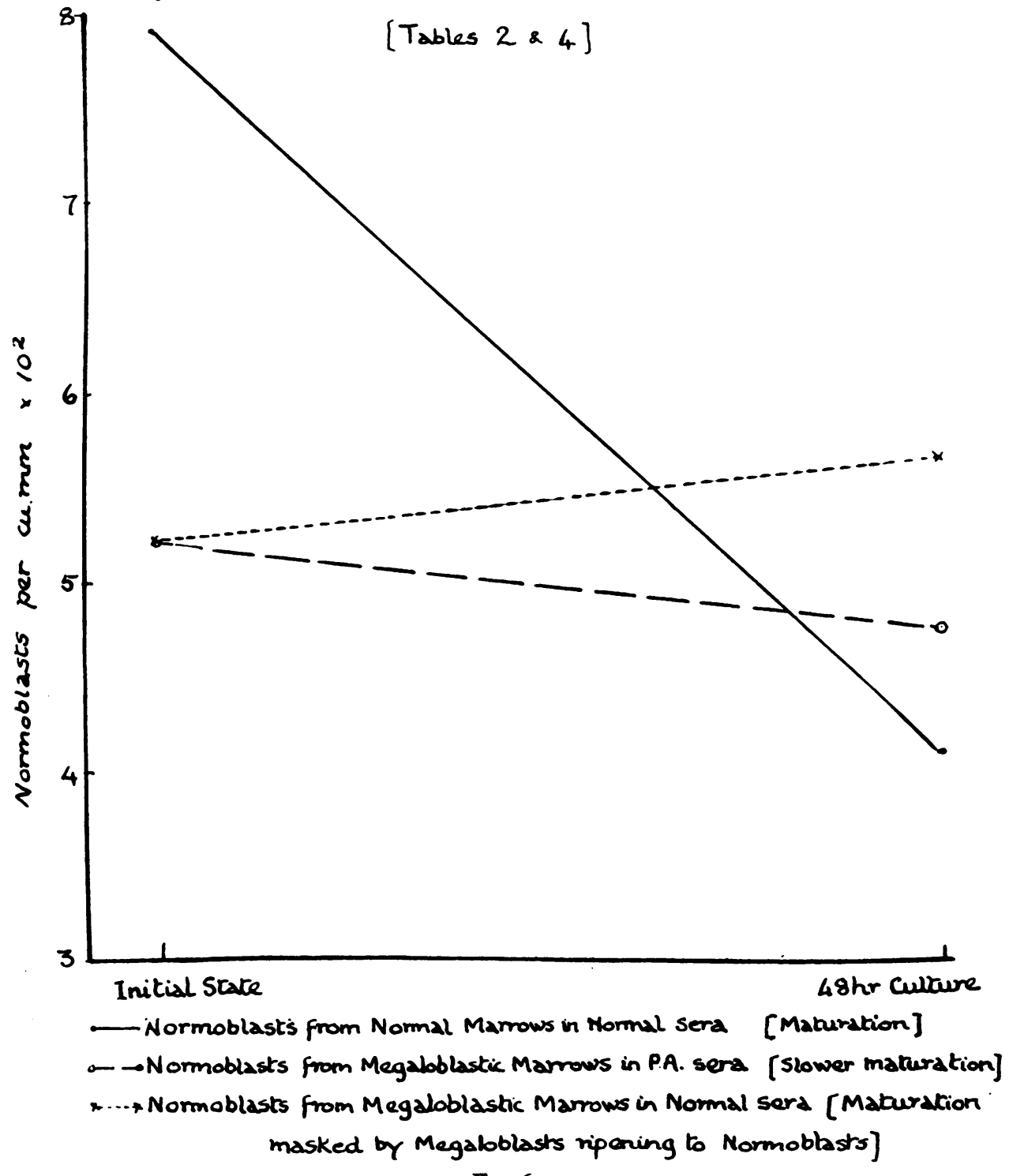

Fig. 6

develop megaloblasts in 48 hours. As normoblasts usually ripen considerably during 48 hours and their number decreases correspondingly, marrows with high erythropoietic activity were found to be the best sources for megaloblast production in vitro. 


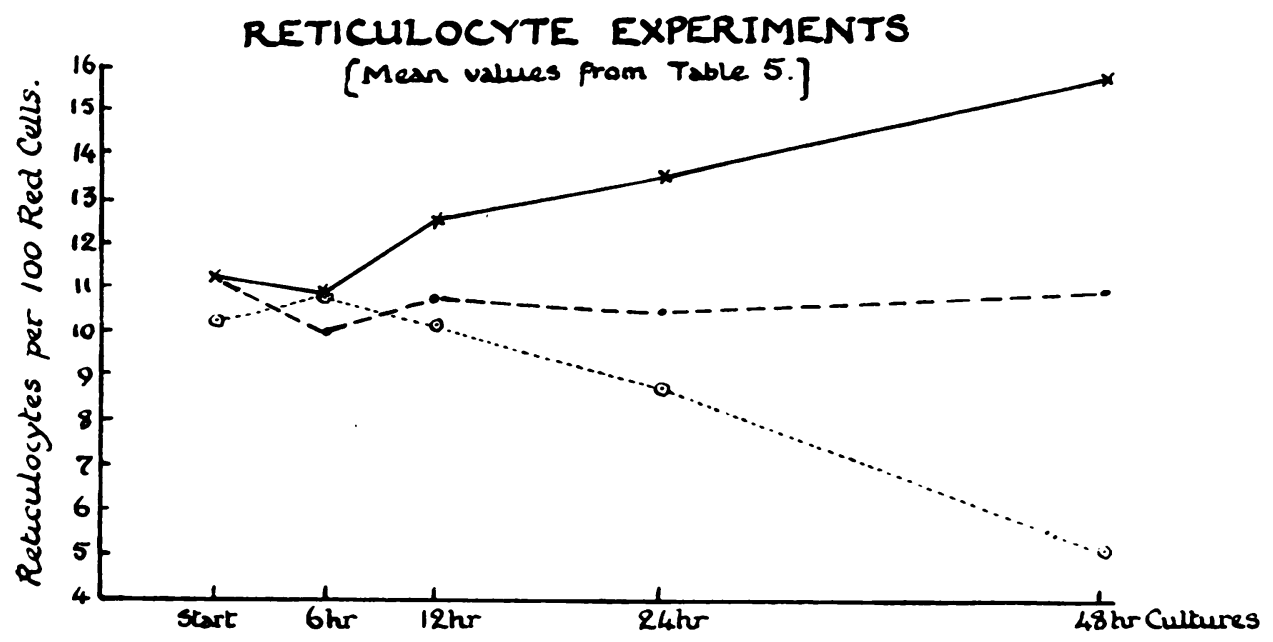

$\longrightarrow$ P.A.Marrow in Normal Serum

-. PA Marrow in P.A Serum a..... Peripheral Blood Fig. 7

The megaloblasts thus produced were not only morphologically classical megaloblasts, but they reacted to folic acid or vitamin $B_{12}$ like those of megaloblastic marrows from pernicious anaemia patients (see photomicrographs).

There is strong evidence that the megaloblasts of this "in vitro pernicious anaemia " were derived from normoblasts. Always numerous transitional "megaloid " forms from normoblasts to megaloblasts were seen, and there was no indication from the mitotic index that the megaloblasts (in one case $28 \%$ ) had developed from a particular "young" cell form.

\section{Discussion}

Attempts have been made to assess the maturation of the nucleated red cells by erythrocyte counting or haemoglobin determination. It was found, however, that none of the existing routine techniques are accurate enough to measure the small changes which occur in vitro. Theoretical calculation has shown that each nucleated red cell would have to produce at least 10 erythrocytes during the 48-hour culture to be able to demonstrate the phenomenon with erythrocyte counting or haemoglobin determination.

It has become evident during the experiments that the total nucleated cell count (which includes the "smear" cells) shows no appreciable changes during the first 24-48 hours of culture. On consideration this is not an unexpected observation because the aged and therefore dying white cells appear as "smear" cells and in the culture bottles there are not enough reticulo-endothelial cells to remove the dying cells (In older cultures the lysis of the aged cells becomes more dominant and the absolute counts show a gradual decrease.) The maturation of the nucleated red cells to 
Transformation of Normoblasts into Megaloblasts in vitro and the effect of Folic Acid AND VITAMIN B 12

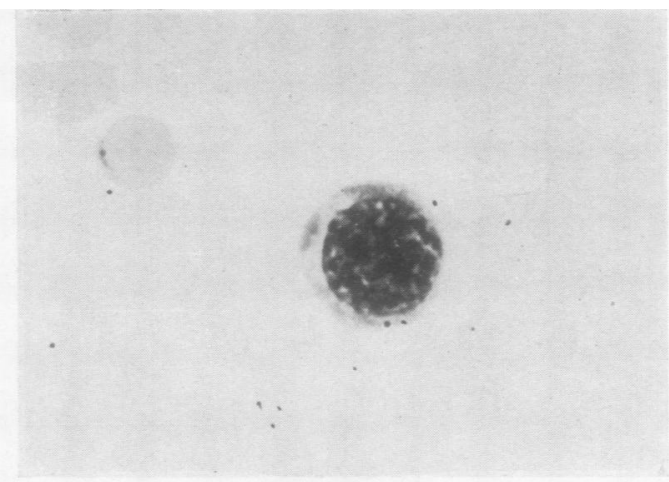

INITIAL STATE

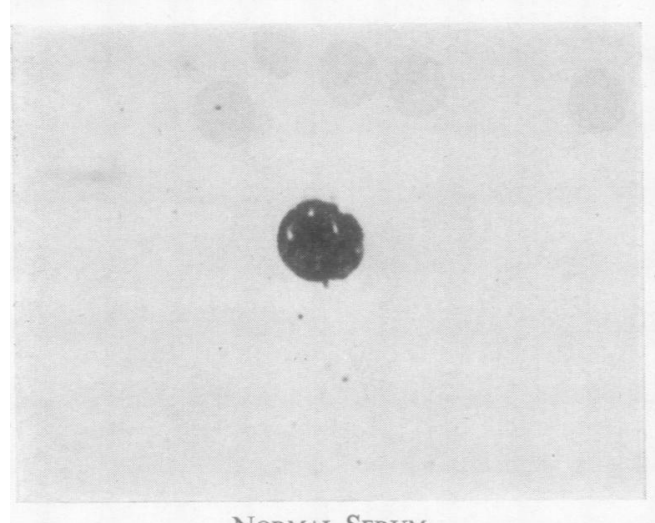

NORMAL SERUM

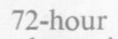

cultures in

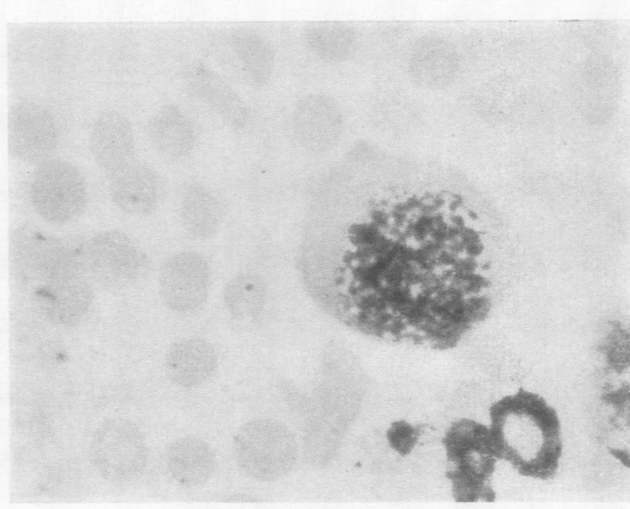

Pernicious Anaemia Serum
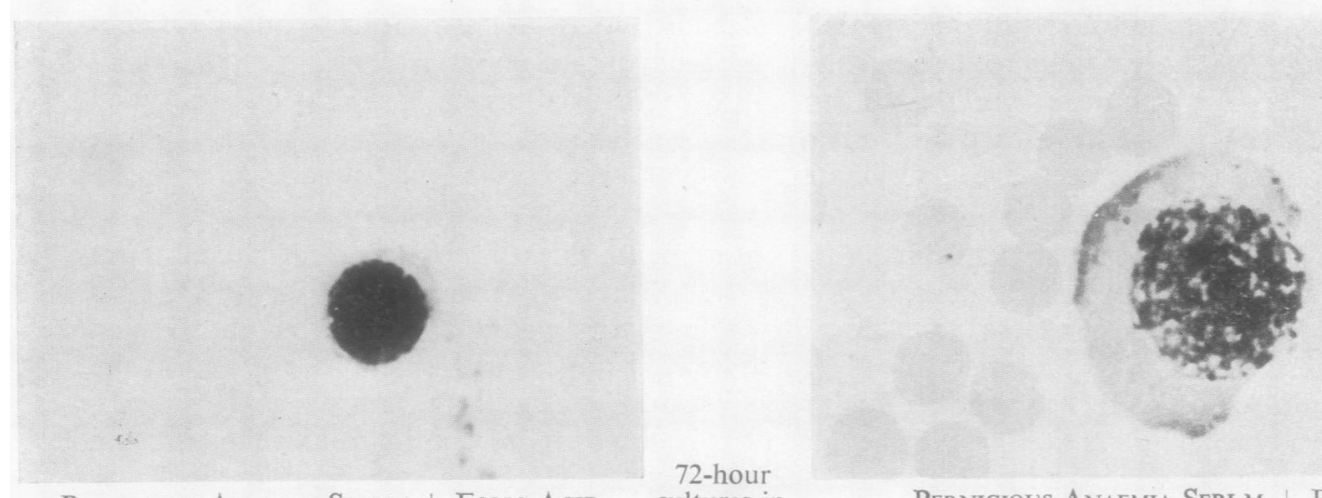
erythrocytes, on the other hand, represents such a small change in the total nucleated cell counts that it is not always statistically evaluable. The changes, however, were always evident from the differential counts and in several experiments the results were obtained by differential counts only.

In using this marrow culture technique it is necessary to work out the personal error which depends on the total nucleated cell counts and the differential counts. With due care the error of total cell counts approaches the Poisson distribution ; with considerable experience and conforming to very strict criteria it is possible to standardize the differential counts so as to approach the binomial distribution. This was in fact the case in the present experiments.

The normoblast-megaloblast interrelationship has been a matter of considerable controversy. The subject has been recently reviewed by Dacie and White (1949). Most workers now agree that transitional forms between the two series of cells do exist and that the megaloblast is a pathological form of normoblast. On the basis of uric acid excretion studies, Frühling has suggested that there is destruction of megaloblasts during response to therapy (Frühling, Mandel, Métais, and Moise, 1950). His findings, however, could equally well be explained by a rapid transformation of megaloblasts to normoblasts with subsequent loss of nuclei as these ripen to reticulocytes.

The observation that originally normoblastic marrows become megaloblastic when cultured in concentrated pernicious anaemia serum in vitro, and the finding that the majority of megaloblasts ripen to normoblasts (and not to megalocytes) when megaloblastic marrows are cultured in normal serum, are strong evidence for the reversibility between the normoblastic and megaloblastic series of cells. This reversibility could be observed at any stage of cell development, and implies that in the pernicious anaemia culture medium there is a change in the metabolism of the normoblasts which results, morphologically, in the megaloblastic form and, functionally, in a slower maturation.

\section{Summary}

A technique is detailed for the culture of human bone marrow in vitro.

Experiments suggesting a reversibility between normoblastic and megaloblastic series of cells are described.

I am greatly indebted to Dr. Rosemary Biggs for her help in the statistical evaluation of the error range of the technique, and to Mr. D. J. Finney for his invaluable help and advice in the assessment of the results of groups of experiments, and for his permission to quote his opinion.

\section{REFERENCES}

Cairns, H. J. F., and Lajtha, L. G. (1948). Nature, Lond., 162, 536.

Callender, S. T., and Lajtha, L. G. (1951a). Journal of Clinical Pathology, 4, 204.

- (1951b). Blood, 6, 1234.

Dacie, J. V., and White, J. C. (1949). Journal of Clinical Pathology, 2, 1.

Ehrlich, P., and Lazarus, A. (1898). In Specielle Pathologie und Therapie, ed. Nothnagel, H., vol. 8. Wien.

Frühling, L., Mandel, P., Métais, P., and Moise, R. (1950). Sang, 21, 541.

Gey, G. O., and Gey, M. K. (1936). Amer. J. Cancer, 27, 45.

Jones, O. P. (1943). Arch Path., Chicago, 35, 752.

- (1947). J. Lab. clin. Med., 32, 700.

___ (1948). Blood, 3, 967. 
Lajtha, L. G. (1950). Clin. Sci., 9, 287.

Naegeli, O. (1931). Blutkrankheiten und Blutdiagnostik, 5th ed. Berlin.

Osgood, E. E., and Brownlee, I. E. (1937). J. Amer. med. Ass., 108, 1793.

Rusznyák, S., Löwinger, S., and Lajtha, L. G. (1948). Hungarica Acta med., $1,9$.

Thompson, R. B. (1951). Personal communication.

\section{STATISTICAL APPENDIX}

In Table VI $\mathrm{s}^{2}$ is approximately equal to the means, and in Table VII $\frac{0.2558 \times 0.7442}{500} \times(100)^{2}$ is approximately equal to 4.8 .

On the basis of statistical analysis of the error of the technique it is possible to assess, in each individual experiment, whether the differences noted are significant or not. Considerable difficulties are met, however, in attempting statistical analysis of groups of experiments. The difficulties arise because of the variability of the material. There is a wide range in the cellular composition of different bone marrows, and similarly a wide range of degree of megaloblastosis in the pernicious anaemia marrows. Thus the initial values for any cell type (orthochromatic normoblasts or megaloblasts) vary considerably from marrow to marrow. Also there are differences in the actions of different normal or different pernicious anaemia sera. The same normal marrow cultured in three different normal sera will behave slightly differently in each, and three different normal marrows cultured in the same normal serum will also behave slightly differently. This applies to megaloblastic marrows and pernicious anaemia sera also.

No appropriate formula could be found which would take into account this inherent variability in the cellular composition of different marrows and in the action of different sera, and would incorporate the external information of the analysis of the error range

TABLE VI

Summary of Statistics of Nucleated Cell Counts in Cultures

\begin{tabular}{|c|c|c|c|c|c|}
\hline \multicolumn{2}{|c|}{ Experiment } & Mean & $\mathrm{s}^{2}$ (random) & s Pipettes (\%) & Total Error (\%) \\
\hline \multirow[t]{2}{*}{$\begin{array}{l}\mathrm{CL} 2 \\
\mathrm{CL} 4 \\
\mathrm{CL} 5\end{array}$} & \multirow[t]{2}{*}{$\begin{array}{l}\mathbf{A} \\
\mathbf{B} \\
\mathbf{A} \\
\mathbf{B} \\
\mathbf{A} \\
\mathbf{B}\end{array}$} & \multirow[t]{2}{*}{$\begin{array}{l}60 \cdot 0 \\
68 \cdot 7 \\
40 \cdot 0 \\
39 \cdot 4 \\
36 \cdot 3 \\
39 \cdot 9\end{array}$} & \multirow[t]{2}{*}{$\begin{array}{r}61 \cdot 6 \\
113.9 \\
28 \cdot 0 \\
66 \cdot 6 \\
36 \cdot 7 \\
46 \cdot 7\end{array}$} & $\begin{array}{l}0 \\
0 \\
0 \\
7 \cdot 4 \\
0 \\
4 \cdot 9\end{array}$ & $\begin{array}{l}13 \cdot 1 \\
15 \cdot 53 \\
13 \cdot 2 \\
22 \cdot 03 \\
16 \cdot 7 \\
23 \cdot 2\end{array}$ \\
\hline & & & & $\begin{array}{l}\text { Total .. } \\
\text { Mean error of } \\
\text { one square }\end{array}$ & $\begin{array}{r}103 \cdot 7 \\
17 \cdot 28\end{array}$ \\
\hline
\end{tabular}

$$
\begin{aligned}
& \text { Error mean of } 8 \text { squares }=\frac{i 7 \cdot 28}{\sqrt{8}}=6 \cdot 1 \% \\
& \text { Error mean of } 16 \text { squares }=\frac{17 \cdot 28}{4}=4 \cdot 32 \%
\end{aligned}
$$

In two experiments where eight squares were counted from each pipette the error found approximates this calculated error.

\begin{tabular}{ll|l|l|l|l}
\hline CL3 & A & $343 \cdot 2$ & $388 \cdot 8$ & $3 \cdot 2$ & $6 \cdot 6$ \\
& B & $330 \cdot 1$ & $807 \cdot 7$ & 0 & $8 \cdot 6$ \\
\hline
\end{tabular}


TABLE VII

ERROR OF DifFERENTIAL COUNTS*

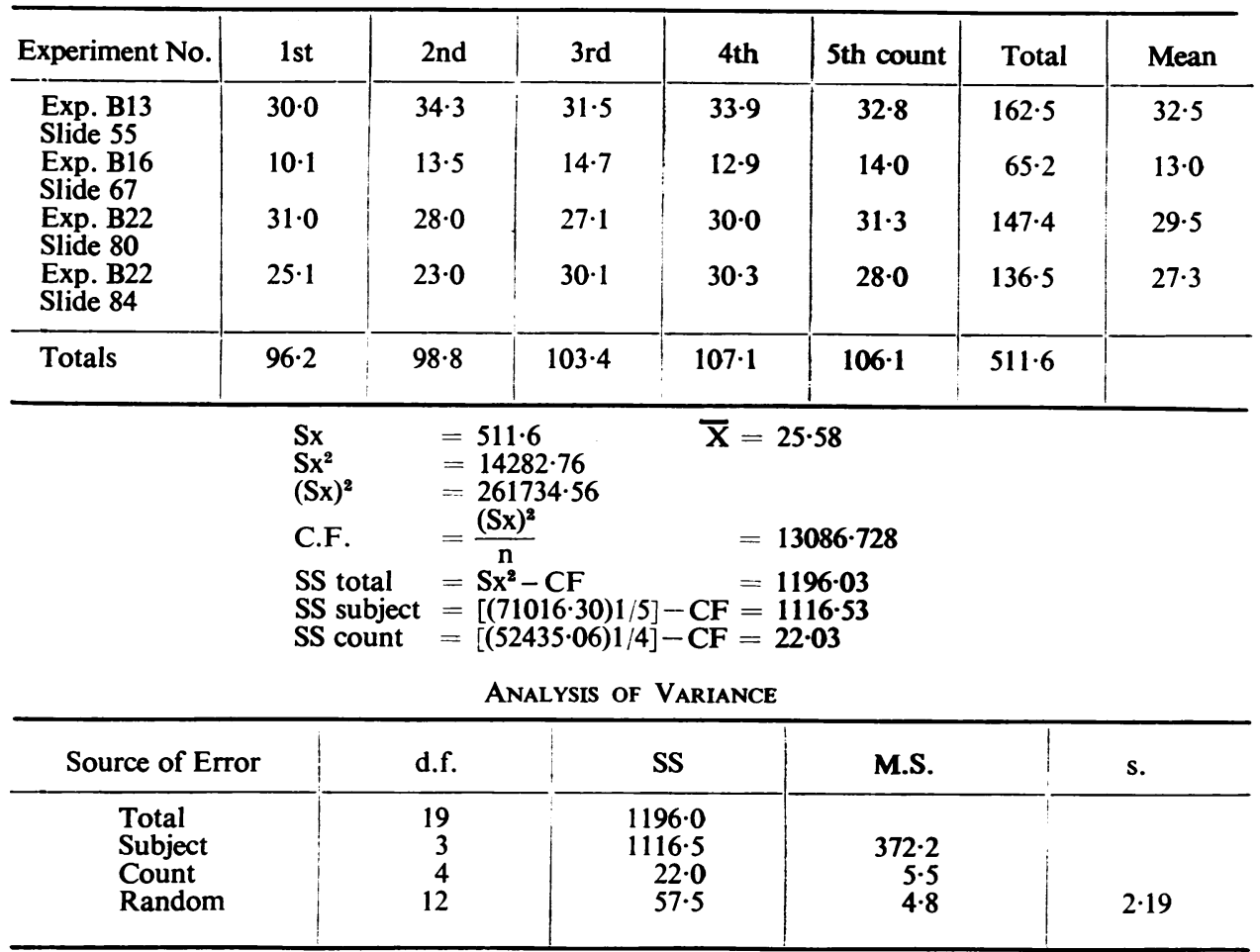

of the technique. A $t$ test of the mean differences was in fact applied to the results of all the culture work to date. This confirmed the impression already formed of the significance of many of the results, but showed far less significance than was expected from sheer common sense, in view of the error range of the technique.

The advice of Mr. D. J. Finney, Lecturer in the Design and Analysis of Scientific Experiment, University of Oxford, was sought. His opinion was :

" The magnitude of the difference between two types of culture varies from subject to subject. The information on errors examined strongly indicates that the difference is significant for each subject taken separately; the $t$ test used on results of groups of experiments, however, would underestimate the degree of this significance because it employs a standard error calculated from the inter-subject variation in the difference and disregards the additional information on errors. Differences which are far outside the error range of the technique must be judged 'significant,' especially when large numbers of experiments on different subjects are taken into account, in the sense that they show clear evidence of some differential effect of type of culture, even though the size of the difference is not the same for all subjects." 